GMP 医薬品・医療用具の品質確保を図るために GMP は, 原料の受入れから最終製品の包装, 出荷 に至るまでの全製造工程において，組織的な管理に基づ く品質保証体制が必要である. WHO は医薬品の製造管 理および品質管理の基準である GMP (Good Manufacturing Practice) の採用を各国に衔告し，わが国では 1980 年より「医薬品の製造管理及び品質管理規則」が, 1987 年より「医療用具の製造所における品質保証に関 する基準 (医療用具 GMP)」が施行されている.

GMP の概要は, (1) 混同・手違いを防止し, 人為的 な䛊りを最小限にすること，(2) 医薬品等に対する污染
および品質低下を防止すること，(3) 高い品質を保証す るシステムを設計すること，である，具体的には，製造 部門之品質管理部門の独立, 製品標準書および作業手順 書等の作成, バリデーションの実施, 教育訓練, すべて の作業の実施記録および製品等の保管出納に関する記録 の作成・保管などが規定されている，また，構造設備に ついても, 外部からの污染の防止, 設備や機器の適切な 配置, 設備や機器の定期点検, 原料や製品の保管設備の 整備, などについて規定されている.

[847 頁] 佐藤 道夫

\section{C形寿命予湘法 プラスチックの寿命予測法の} 形寿命予測法 具体的な手法のひとつ. C 字形 （割り円環状）の試験片を用い，その両端部分の二つの 孔をピンで回転を自由に固定し, 外力を付加して孔間距 離を拡大すると, 試験片の中央部分の外縁部に最大引張 応力, 内縁部に最大圧縮応力が発生し, 応力分布が形成 される. それぞれの応力值は, 弾性論に基づく関係式に より求まる．このC 形試験片の特徵は，(1) 円形である ため, 射出成形や切削加工が容易. (2) 小さい外力で 大きな応力分布を与えられる. (3) 応力の大きい 中央部分を液体に浸漬しながら応力分布を与え られる. (4) チャックを漫漬せず, 劇薬や

\section{ถดำำ}

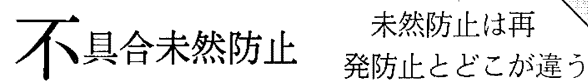

のだろうか. 再発防止は実際に生じた不具合の予

防策を二度と起こさせない観点加ら管理に展開するこ とで目的が達成される. しかし，再発防止のポイントが 多くなると，管理が複雑になり管理のための管理が横行 する拈それがでてくるし，再発防止を中心とした管理手 法だけでは新製品を次々と提供する必要のある現在にお いては問題がくい止められなくなってくる．これに対し 不具合未然防止は, 今まで経験しなかった新しい不具合 あ起こさない, 何とか防止したいということで, 設計し たシステムの弱点を事前に見つけだし設計的に対処して おくことにより目的が達成されるあのである.
腐食性の薬液す適用できる. (5) 両端の孔間距離の変化 を計測すると, C 形試験片の剛性変化が追跡でき, 見か けの曲げ弾性率の変化が求まる. (6) 浸潰時間に伴う応 力緩和曲線が求まる。 (7) 偏光板を併用すると, ケモレ オロジカルなデー夕も得られる.C形劣化解析装置を組 み上げ，そのデータとプラスチックの実用現場に抢ける 12 年に及ぶフィールドテストとの相関が求まり, 繰返 し応力と環境薬液との相乗作用による劣化（環境・応力 劣化）に対する年間の害用寿命を 30 分の測定で予 測できる寿命予測法が確立された。

[840 頁] 大石不二夫

\section{Bellcore 規格 Bellcore は, 米国の Bell Com-} Bellcore 規格 munications Research, Inc. の ことである.この Bellcore社が作成した規格をBellcore 規格と称しており, 通信分野におけるシステム, 装置, 部品に関する多数の䙺格が制定されている. よく 知られている規恪として, 国際標準化機構の ISO 規格, 国際電気標準会議の IEC 規格, 日本の JIS 規格, 米国 国防省の MIL 規格などがあるが，通信分野では Bellcore 規格が世界的に引用されている. Bellcore 規格の 中の高分子材料が関係する内容として, GR-1209CORE「光分岐部品に対する一般的要求」には以下の要 求事項がある. (1) 毒性：人が触れる可能性のある部分
の材料は毒性がないこと，および，環境に関する法律な どに示されているような危険を与えないこと，毒性のあ る材料を使うときは使用者に必要な知識を与えること.

(2) 耐菌性：部品の外側に使う高分子材料は菌を増殖し ないこと. (3) 燃焼性：部品の外側に使う高分子材料は 酸素指数が $28 \%$ 以上であること，おうよび，燃焼試験で 炎を取り去ったのちに燃燒が継続しないこと，また， GR-1221-CORE「受動光部品に対する信頼性保証要 求」には, 部品製造に使う接着剂の信頼性に関する要求 事項が詳細に記載されている。

[850 頁］花房 廣明, 福田 光男 